\title{
Multiplex Real-time PCR Detection and Differentiation of Colletotrichum Species Infecting Soybean
}

Hui-Ching Yang, Department of Natural Resources and Environmental Sciences, James S. Haudenshield, USDA Agricultural Research Service, and Glen L. Hartman, USDA Agricultural Research Service, Department of Crop Sciences, and Department of Natural Resources and Environmental Sciences, University of Illinois, Urbana, IL 61801, USA

\begin{abstract}
Yang, H.-C., Haudenshield, J. S., and Hartman, G. L. 2015. Multiplex real-time PCR detection and differentiation of Colletotrichum species infecting soybean. Plant Dis. 99:1559-1568.

Colletotrichum species are fungal plant pathogens of worldwide significance. Colletotrichum species were isolated from soybean with anthracnose symptoms in five states in the United States from 2009 to 2013. Among 240 isolates collected, four Colletotrichum species were initially identified by morphological and sequence analysis, including C. chlorophyti, C. incanum, C. truncatum, and Colletotrichum sp. (henceforth Glomerella glycines, the name of its sexual state). To increase diagnostic efficiency and accuracy, real-time multiplex PCR assays based on a double-stranded DNA-binding dye coupled with dissociation curve analysis were designed, using a region of the cytochrome $\mathrm{c}$ oxidase subunit 1 ( $\operatorname{coxl} 1)$ gene to discern these four Colletotrichum species. Two sets of duplex, real-time PCR assays were established and species differentiation

was based upon amplicon melting point temperatures $\left(\mathrm{T}_{\mathrm{m}}\right)$ in the dissociation curve analysis. The Set 1 duplex assay distinguished $C$. chlorophyti and G. glycines, and the Set 2 duplex assay distinguished $C$. incanum and C. truncatum. Successful detection was achieved with as little as $1 \mathrm{pg}$ DNA. The assays were especially useful for differentiating $C$. chlorophyti, $C$. incanum, and $C$. truncatum, which have similar morphological features. Colletotrichum gloeosporioides, another pathogen associated with soybean anthracnose, was not resolved from G. glycines by the melting curve analysis. The two duplex real-time PCR assays were used to screen more than 200 purified Colletotrichum isolates, showing that they were rapid and effective methods to detect and differentiate $\mathrm{Col}$ letotrichum species infecting soybean.
\end{abstract}

Colletotrichum species cause anthracnose on soybean (Glycine $\max$ (L.) Merr.) worldwide (Manandhar and Hartman 1999), with yield losses ranging from 16 to $100 \%$ in Brazil, India, Thailand, and southern areas in the United States (Backman et al. 1982; Manandhar and Hartman 1999; Wrather and Koenning 2006). The pathogens can infect plants at any growth stage, although symptoms may be more apparent when the plants reach maturity, or under humid and warm conditions. Typical symptoms include irregularly shaped, brown and black blotches, and sunken cankers on the stems, petioles, and pods. Infected leaves may be shrunken, rolled, or wilted, and may have necrotic laminar veins, resulting in premature defoliation of the plants. Infected seeds often become discolored, and may die during germination (Manandhar and Hartman 1999).

Colletotrichum truncatum is the most commonly reported pathogen that causes soybean anthracnose. Other species were also reported to cause this disease, including Glomerella glycines [asexual stage previously reported as $C$. destructivum; currently being described as a different species from $C$. destructivum, based upon DNA sequences (Damm et al. 2013)], C. coccodes, C. gloeosporioides (sexual stage, G. cingulata), and C. graminicola (sexual stage, G. graminicola) (Tiffany and Gilman 1954; Roy 1982; Manandhar et al. 1986; Riccioni et al. 1998; Manandhar and Hartman 1999). Recently, C. chlorophyti and a new species, $C$. incanum, were discovered to infect soybean (Yang et al. 2012; 2014; Yang et al. 2013), and cause anthracnose. Among these species, $C$. graminicola has been infrequently reported on soybean, but causes a major disease on Zea mays (Nicholson 1992).

Methods to diagnose and discriminate among Colletotrichum species include utilizing morphological characteristics, such as the size

Corresponding author: G. L. Hartman; E-mail: Glen.Hartman@ars.usda.gov

Accepted for publication 12 April 2015.

http://dx.doi.org/10.1094/PDIS-11-14-1189-RE

This article is in the public domain and not copyrightable. It may be freely reprinted with customary crediting of the source. The American Phytopathological Society, 2015. and shape of conidia and appressoria, and the presence or absence of perithecia and sclerotia. Cultural characteristics including colors, textures, and radial growth rates on different culture media are also used for classification purposes (Tiffany and Gilman 1954; Arx 1957; Sutton 1980, 1992). However, these criteria are not always adequate for reliable differentiation because of the variation in morphology caused by field environmental factors and/or cultural conditions (media and temperature). In addition, using morphological characteristics as the diagnostic method can be time-consuming when identifying numerous fungal isolates.

The use of molecular technologies like polymerase chain reaction (PCR), restriction fragment length polymorphisms, random amplified polymorphic DNA assays, and amplified fragment length polymorphisms to enhance detection and provide molecular comparisons of Colletotrichum species have been reviewed (Thaung 2008). In addition to the electrophoretic procedures, real-time, quantitative PCR assays have been developed and shown to be sensitive, reproducible, and a rapid means of detecting and quantifying plant pathogens (Schena et al. 2004; Deepak et al. 2007). This technology has become an effective tool to specifically detect several Colletotrichum species, such as $C$. acutatum on strawberries and grapevines (Debode et al. 2009; Garrido et al. 2009), C. coccodes in soil and on potato tubers (Cullen et al. 2002), C. kahawae on coffee (Tao et al. 2013), and C. lagenarium on cucurbit crops (Kuan et al. 2011). Of the described molecular approaches used to detect or distinguish Colletotrichum species in other crops, only a gel-based multiplex-PCR method has been used to distinguish $C$. gloeosporioides and $C$. truncatum on soybean (Chen et al. 2006).

Real-time PCR assays utilizing fluorescent dyes (e.g., SYBR Green I) which intercalate into double-stranded (ds) DNA are commonly used to detect pathogens, as are fluorogenic probe-based assays (e.g., Taqman) (Schena et al. 2004). The use of dye-binding real-time PCR, coupled with dissociation (or melting) curve analysis of the amplification products, is potentially more cost-effective than using probe-based assays, and has been applied widely to detect and differentiate pathogens in clinical and animal studies, such as Plasmodium spp. (Mangold et al. 2005), adenovirus (Steer et al. 2009), microsporidian species (Polley et al. 2011), Candida spp. (Hays 
et al. 2011), Aspergillus spp. (Fricke et al. 2012), diarrheagenic Escherichia coli strains (Barletta et al. 2013), and porcine reproductive and respiratory syndrome viruses (Chai et al. 2013). In plant disease diagnostics, the technique has been applied to distinguish potato cyst nematodes (Bates et al. 2002), sugarcane nematodes (Berry et al. 2008), wood rotting fungi (Horisawa et al. 2013), potato viruses (Cheng et al. 2013), and tomato viruses (Wieczorek and Obrepalska-Steplowska 2013). However, this technique has not been customarily used to detect, identify, and distinguish species of Colletotrichum.

Many real-time PCR assays for detecting fungal species have been designed to target the rDNA-internal transcribed spacer (ITS) regions. ITS regions are less conserved than coding regions, and have been used to detect species divergence, including species of Colletotrichum (Hillis and Dixon 1991; Sherriff et al. 1994; Thaung 2008). Other regions also may be suitable; for example, a gene region of glyceraldehyde-3-phosphate dehydrogenase (GAPDH) has been used for species-specific real-time PCR detection of C. kahawae (Tao et al. 2013). In addition, the mitochondrial cytochrome c oxidase gene, coxl, was reported as a better phylogenetic marker than the ITS regions to speciate soil fungi belonging to Ascomycota and Zygomycota with a higher taxonomic resolution (Molitor et al. 2010). Another advantage of using coxl as a target for detection was that its mRNA could be used as an indicator of metabolic activity of the fungal communities in environmental samples (Damon et al. 2010). Although coxl has been utilized in phylogenetic analyses, its application in real-time PCR diagnostics of fungal species has not been reported.

In this research, 240 Colletotrichum isolates from soybean petioles and stems bearing signs of the fungus were cultured from 2009 to 2013. Recognizing the sensitivity and dispatch of realtime PCR and the utility of the coxl gene as a marker for distinguishing among species within the phylum Ascomycota, the present study aimed to develop multiplex real-time PCR assays based on the dsDNA dye-binding method, targeting the coxl gene to rapidly identify and accurately differentiate Colletotrichum species infecting soybean.

\section{Materials and Methods}

Collection, isolation, and maintenance of Colletotrichum species. Stem and petioles of soybean plants with irregular black acervuli were collected from eight Illinois counties (Champaign, DeKalb, Iroquois, Ogle, Sangamon, Warren, Whiteside, and Woodford), three southern states including Alabama (Baldwin County), Arkansas (Crawford County), and Mississippi (Washington County), and one northern state, North Dakota (Foster County), during 2009, 2011, and 2013. All samples were collected when the plants were at harvest maturity. Petioles and stems were surface-disinfested as previously described (Yang et al. 2014). Briefly, plant tissues were cut into 1 - to $2-\mathrm{cm}$ pieces and sequentially immersed in sterile water for $5 \mathrm{~min}, 95 \%$ alcohol for $3 \mathrm{~min}$, $1.2 \%(\mathrm{w} / \mathrm{w})$ sodium hypochlorite (from commercial bleach) for 5 to $7 \mathrm{~min}$, and twice in sterile water for 3 to $5 \mathrm{~min}$. Then the pieces were placed on water agar (BD Bacto, Sparks, MD) and incubated at room temperature $\left(23 \pm 2{ }^{\circ} \mathrm{C}\right)$ in the dark until fungal colonies developed. Culture purity was achieved by single-spore isolation from fungal fruiting structures (acervuli and/or perithecia) or by hyphal-tip culture from mycelia growing on the agar. The pure isolates were transferred and maintained in an incubator (Percival Scientific, Inc., Boone, IA) at $24 \pm 1{ }^{\circ} \mathrm{C}$ under $12 \mathrm{~h}$ cool-white fluorescent lighting $\left(45 \mu \mathrm{mol} / \mathrm{m}^{2} / \mathrm{s}\right)$ on potato dextrose agar (PDA) (BD Difco, Sparks, MD) or acidified PDA (APDA; pH 4.5) made with $550 \mu \mathrm{l}$ of $85 \%(\mathrm{w} / \mathrm{w})$ lactic acid (Fisher Scientific, Fair Lawn, NJ) per liter PDA. Species identifications of isolates were based on morphological classification of cultural characteristics (colors and textures on APDA plates) and sequences of rDNAITS regions (ITS1, 5.8S, ITS2) amplified with primers ITS1 and ITS4 (White et al. 1990) as previously described (Yang et al. 2014).

DNA extraction, amplification, and sequencing of the cox1 gene. Total genomic DNA of each isolate was extracted from 10- to 14-day-old mycelia grown on PDA, using the FastDNA Spin Kit and FastPrep instrument (MP Biomedicals, Solon, OH). Primers coxu 1 and coxr1 (Molitor et al. 2010) were used at a final concentration of $500 \mathrm{nM}$ to amplify the partial coxl gene. PCR reactions were assembled using the Phusion High-fidelity PCR Kit (New England Biolabs, Ipswich, MA), and performed in a PTC-100 Programmable Thermal Controller (MJ Research, Inc., Watertown, MA) with an initial denaturation step of $98^{\circ} \mathrm{C}$ for $30 \mathrm{~s}$, followed by 35 cycles of $10 \mathrm{~s}$ at $98^{\circ} \mathrm{C}, 30 \mathrm{~s}$ at $53^{\circ} \mathrm{C}$, and $30 \mathrm{~s}$ at $72^{\circ} \mathrm{C}$, and a final extension step of $72^{\circ} \mathrm{C}$ for $7 \mathrm{~min}$. The amplification products were purified using the E.Z.N.A MicroElute Cycle Pure Kit (Omega Bio-Tek, Inc., Norcross, GA) and delivered to the core DNA sequencing facility of the Roy J. Carver Biotechnology Center (University of Illinois, Urbana, IL) for bidirectional Sanger sequencing using the same primers as used for amplification. Nucleotide sequences were aligned using Clustal W (Thompson et al. 1994) implemented in BioEdit v7.1.3 (Hall 1999).

Real-time PCR primer design and reactions. Real-time PCR primers for dsDNA-binding dye assays were designed using Beacon Designer software (Premier Biosoft, Palo Alto, CA) based on the alignment of partial coxl sequences of four reference isolates (IL1A, IL6A, IL15B, and IL18A), which were previously identified by multigene phylogenetic analysis as $C$. chlorophyti, $C$. incanum, C. truncatum, and G. glycines, respectively (Yang et al. 2014). For the purpose of multiplex real-time PCR, primer pairs were designed to specifically detect each species and to have unique product melting point temperature $\left(\mathrm{T}_{\mathrm{m}}\right)$ values predicted by the software. The four primer pairs corresponding to the four Colletotrichum species are shown in Table 1, and their positions in the aligned sequences are shown in Figure 1.

Real-time PCR reactions were prepared using a ready-to-use mixture, SsoFast EvaGreen Supermix with low ROX (Bio-Rad, Hercules, CA). Each $20-\mu l$ real-time PCR reaction contained $1 \times$ EvaGreen Supermix, $200 \mathrm{nM}$ of each primer, and $100 \mathrm{pg}$ of each fungal DNA. The reactions were performed using a Stratagene Mx3005p thermal cycler (Agilent Technologies, Santa Clara, CA) with the following program: a cycle of denaturation at $95^{\circ} \mathrm{C}$ for $2 \mathrm{~min}, 30$ cycles of $95^{\circ} \mathrm{C}$ for $10 \mathrm{~s}$, and $55^{\circ} \mathrm{C}$ for $30 \mathrm{~s}$, with an endpoint detection of fluorescence intensity in each cycle. For dissociation

Table 1. Primer sequences designed for EvaGreen real-time PCR assays based on partial coxl gene to differentiate Colletotrichum chlorophyti, C. incanum, C. truncatum, and Glomerella glycines

\begin{tabular}{|c|c|c|c|c|c|c|}
\hline Duplex PCR & Target & Primer & Orientation & Primer sequence $5^{\prime} \rightarrow 3^{\prime}$ & Product size (bp) & Product $T_{m}\left({ }^{\circ} C\right)^{a}$ \\
\hline \multirow[t]{4}{*}{ Set 1} & C. chlorophyti & $\operatorname{cox} 1 \mathrm{AF}$ & Forward & CCTGGTATAAGATTACATAAG & 115 & $75.36 \pm 0.25$ \\
\hline & & $\operatorname{cox} 1 \mathrm{AR}$ & Reverse & CTGTAAGTACCATAGTAATTG & & \\
\hline & G. glycines & $\operatorname{cox} 18 \mathrm{AF}$ & Forward & ACATTTATCAGGAGTAAGTAG & 77 & $71.63 \pm 0.22$ \\
\hline & & cox18AR & Reverse & TTCCAGGTGTTCTCATAT & & \\
\hline \multirow[t]{4}{*}{ Set 2} & C. incanum & $\operatorname{cox} 6 \mathrm{AF}-2$ & Forward & ATGAACATTATATCCTCCTT & 115 & $75.79 \pm 0.23$ \\
\hline & & cox6AR-2 & Reverse & ATTAACTGCTCCTAATAAAC & & \\
\hline & C. truncatum & $\operatorname{cox} 15 \mathrm{BF}$ & Forward & TTATGCCAGCCTTAATAG & 117 & $77.39 \pm 0.34$ \\
\hline & & $\operatorname{cox} 15 \mathrm{BR}$ & Reverse & AAGATGGTGGTAATAATCA & & \\
\hline
\end{tabular}

\footnotetext{
a The mean and standard deviation of the $\mathrm{T}_{\mathrm{m}}$ value was based on the results of 12 independent tests.
} 
curve analysis, a subsequent denaturation at $95^{\circ} \mathrm{C}$ for $1 \mathrm{~min}$, and annealing at $65^{\circ} \mathrm{C}$ for $30 \mathrm{~s}$ was followed by a gradual ramp to $95^{\circ} \mathrm{C}$ with continuous detection of fluorescence to monitor strand dissociation. The instrument-included software (MxPro v.4.10) calculated and charted the negative first derivative of raw fluorescence as a function of increasing temperature to produce one or more sharp peaks corresponding to the $\mathrm{T}_{\mathrm{m}}$ of amplification products, where dsDNA transitioned to ssDNA.

Multiplex real-time PCR assays. Quadruplex real-time PCR was tested by mixing four primer pairs (Table 1) in a reaction. Two sets of duplex real-time PCR were tested by separating the quadruplex into two duplex assays: Set 1 (containing two primer pairs, cox1AF + cox $1 \mathrm{AR}$ and cox $18 \mathrm{AF}+\operatorname{cox} 18 \mathrm{AR}$ ) was designed to specifically differentiate $C$. chlorophyti and G. glycines; Set 2 (containing two primer pairs, cox6AF-2 + cox6AR-2 and cox $15 \mathrm{BF}+\operatorname{cox} 15 \mathrm{BR})$ was designed to specifically differentiate $C$. incanum and C. truncatum. The reaction mixtures of multiplex real-time PCR were prepared as described above with $200 \mathrm{nM}$ of each primer and 100 pg DNA of each fungal DNA in a reaction. Real-time PCRs and dissociation curve analyses were performed as described above. Reference isolates IL1A (C. chlorophyti), IL6A (C. incanum), IL15B (C. truncatum), and IL18A (G. glycines) were used to test the performance of the multiplex assays. The $\mathrm{T}_{\mathrm{m}}$ value (mean \pm standard deviation) of each reference isolate was calculated based on the results of 12 independent tests of the two duplex real-time PCR assays.

Sensitivity and specificity of the duplex real-time PCR assays. To test the assay sensitivity, the DNAs of the reference isolates
ILIA (C.chlorophyti)

IL6A (C. incanum)

IL15B (C.truncatum)

IL18A (G.glycines)

ATCC58222 (C.gloeosporioides)

IL1A (C.chlorophyti)

IL6A (C. incanum)

IL15B (C.truncatum)

IL18A (G.glycines)

ATCC58222 (C.gloeosporioides)

IL1A (C. chlorophyti)

IL6A (C. incanum)

IL15B (C.truncatum)

IL18A (G.glycines)

ATCC58222 (C.gloeosporioides)

IL1A (C.chlorophyti)

IL6A (C. incanum)

IL15B (C.truncatum)

IL18A (G.glycines)

ATCC58222 (C.gloeosporioides)

IL1A (C.chlorophyti)

IL6A (C. incanum)

IL15B (C.truncatum)

IL18A (G.glycines)

ATCC58222 (C.gloeosporioides)

IL1A (C. chlorophyti)

IL6A (C. incanum)

IL15B (C. truncatum)

IL18A (G.glycines)

ATCC58222 (C.gloeosporioides)

IL1A (C. chlorophyti)

IL6A (C. incanum)

IL15B (C.truncatum)

IL18A (G.glycines)

ATCC58222 (C.gloeosporioides)
GGTACAGCTTTCTCTGTATTAATAAGATTAGAATTAAGTGGACCAGGTGTTCAATATATTTCGGATAACCAATTATATAA

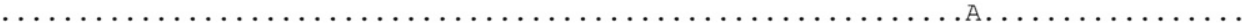

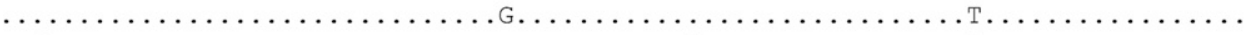

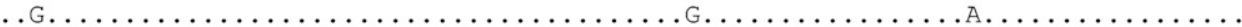

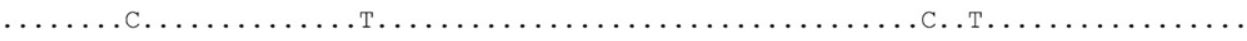

$\begin{array}{rrrrrrr}90 & 100 & 110 & 120 & 130 & 140 & 150\end{array}$ TAGTATAATTACAGCGCACGCCATATTAATGATATTCTTTATGGTTATGCCTGCATTAATAGGAGGTTTTGGTAACTTTT

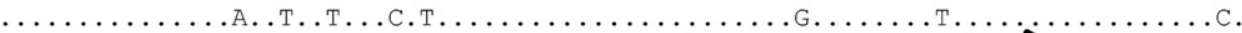

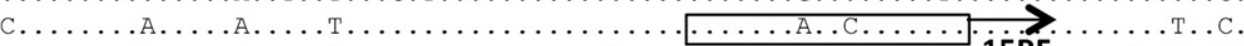


$\ldots \ldots \ldots$ А. .....

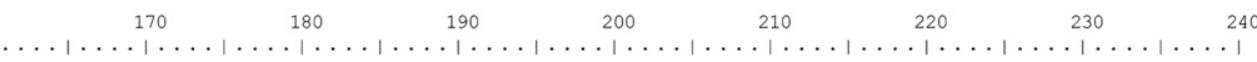
TAATGCCTTTAATGGTAGGAGGGCCTGATATGGCATTCCCTAGATTAAATAATATAAGTTTCTGATTATTACCACCTAGT

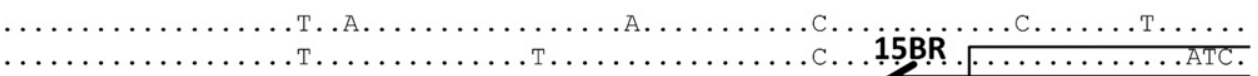

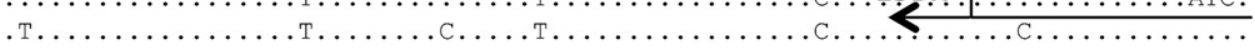
т.

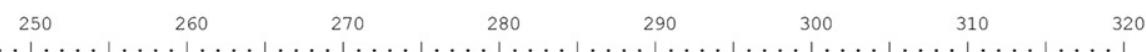
TTAATACTATTAGTATTCTCTGCATGTATAGAAGGTGGAGTTGGTACAGGTTGAACTTTATACCCTCCTTTATCAGGATT

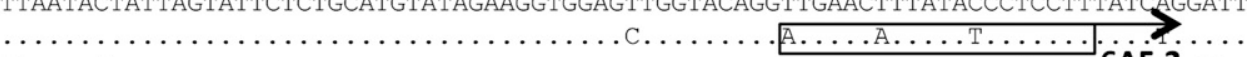



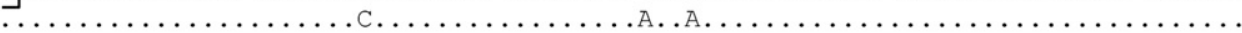

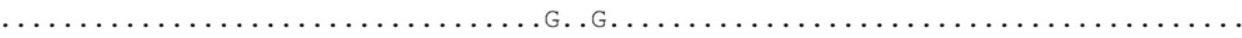
$\begin{array}{rrrrrrr}330 & 340 & 350 & 360 & 370 & 380 & 390\end{array} 400$ ACAAAGTCATAGTGGACCTAGTGTAGATTTAGCTATATTTGCTTTACATTTATCTGGAGTAAGTAGTTTATTAGGATCTA

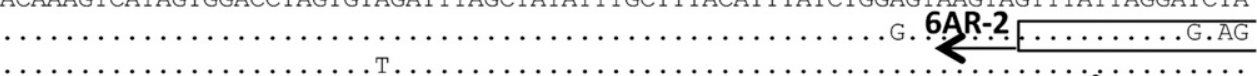

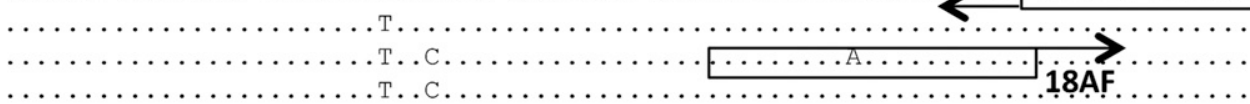

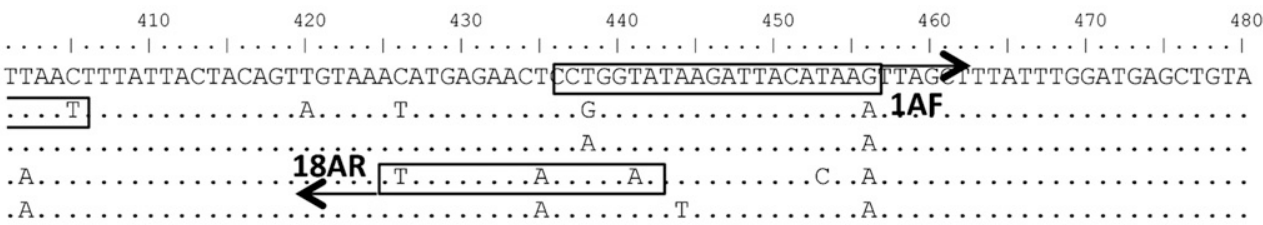

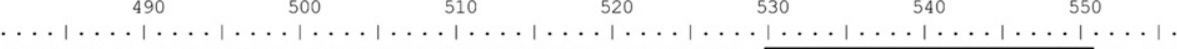
GTTATAACAGCTGTATTATTATTATTATCTTTACCTGTACTTGCAGGAGEATTACTATGGTACTTACAGATAGAA

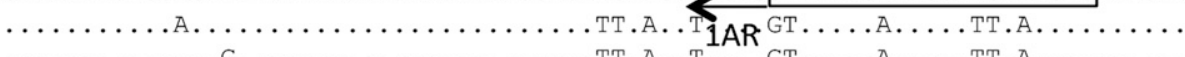
$\ldots \ldots \ldots \ldots$. . . . . . . . . . . . . . . . . . . . . . $\ldots \ldots \ldots \ldots \ldots \ldots \ldots \ldots \ldots \ldots \ldots \ldots \ldots \ldots \ldots \ldots \ldots \ldots \ldots \ldots \ldots \ldots \ldots \ldots \ldots \ldots \ldots \ldots \ldots \ldots$

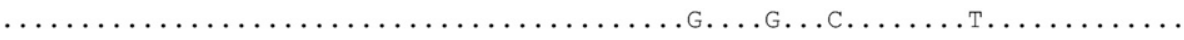

Fig. 1. Real-time PCR primer positions on the aligned cox1 sequences of four Colletotrichum reference isolates representing $C$. chlorophyti, $C$. incanum, $C$. truncatum, and Glomerella glycines, respectively. An ATCC strain of $C$. gloeosporioides is included for comparison. Identical nucleotides are shown by dots. The four primer pairs and their directions are highlighted. 
(IL1A, IL6A, IL15B, and IL18A) were diluted. For each isolate, $1,000,100,10,1$, and $0.1 \mathrm{pg}$ were tested, with two technical replicates.

Thirty-five isolates, including the four reference isolates, were then used to validate assay specificity (Table 2). These isolates were previously identified with methods combining morphological characteristics and sequence analyses as previously described (Yang et al. 2014) and belong to the four Colletotrichum species previously described. Other Colletotrichum species, including C. coccodes (from soybean), C. gloeosporioides (from soybean), C. acutatum (from chili pepper), and C. orbiculare (from watermelon), and other unrelated fungal pathogens of soybean, were also tested, including species of Cercospora, Fusarium, Macrophomina, and Diaporthe/Phomopsis (Table 2).

Identification of Colletotrichum isolates by real-time PCR. Duplex real-time PCR assays were used to detect and differentiate 205 Colletotrichum isolates that had not been identified by sequence analysis. Isolates were incubated on APDA plates for 10 to 14 days before mycelial DNAs from the colony were extracted as previously described. DNA of each isolate was subjected to the duplex real-time PCR assays, with DNA from IL1A, IL6A, IL15B, and IL18A isolates used as controls in parallel. The identification of each isolate was achieved by comparing the $\mathrm{T}_{\mathrm{m}}$ produced by the dissociation curves with those of the controls.

Table 2. Colletotrichum and other fungal isolates used for the study with their hosts, origins, and real-time PCR detection results

\begin{tabular}{|c|c|c|c|c|c|c|}
\hline \multirow[b]{2}{*}{ Species } & \multirow[b]{2}{*}{ Isolate } & \multirow[b]{2}{*}{ Host } & \multirow[b]{2}{*}{ Origin } & \multicolumn{2}{|c|}{$\begin{array}{c}\text { Real-time PCR } \\
\text { detection }^{\mathrm{a}}\end{array}$} & \multirow[b]{2}{*}{ Product $\mathbf{T}_{\mathbf{m}}\left({ }^{\circ} \mathbf{C}\right)$} \\
\hline & & & & Set 1 & Set 2 & \\
\hline \multicolumn{7}{|l|}{ Colletotrichum species } \\
\hline \multirow[t]{7}{*}{ C. chlorophyti } & $\mathrm{IL} 1 \mathrm{~A}^{\mathrm{b}}$ & Glycine $\max$ & IL & + & - & 75.25 \\
\hline & IL2A & G. $\max$ & IL & + & - & 75.20 \\
\hline & IL3A & G. $\max$ & $\mathrm{IL}$ & + & - & 75.20 \\
\hline & IL4A & G. $\max$ & $\mathrm{IL}$ & + & - & 75.20 \\
\hline & IL31 & G. $\max$ & IL & + & - & 76.10 \\
\hline & MS1 & G. $\max$ & MS & + & - & 76.15 \\
\hline & ALO & G. $\max$ & $\mathrm{AL}$ & + & - & 75.65 \\
\hline \multirow[t]{14}{*}{ C. incanum } & $\mathrm{IL} \mathrm{A}^{\mathrm{b}}$ & G. $\max$ & IL & - & + & 75.60 \\
\hline & IL7A & G. $\max$ & IL & - & + & 75.65 \\
\hline & IL8A & G. $\max$ & $\mathrm{IL}$ & - & + & 75.65 \\
\hline & IL9A & G. $\max$ & IL & - & + & 75.60 \\
\hline & IL10A & G. $\max$ & IL & - & + & 75.80 \\
\hline & IL11A & G. $\max$ & $\mathrm{IL}$ & - & + & 75.75 \\
\hline & IL12A & G. $\max$ & IL & - & + & 75.75 \\
\hline & IL13A & G. $\max$ & IL & - & + & 75.65 \\
\hline & IL14A & G. $\max$ & $\mathrm{IL}$ & - & + & 75.60 \\
\hline & IL29 & G. $\max$ & $\mathrm{IL}$ & - & + & 75.65 \\
\hline & IL30 & G. $\max$ & IL & - & + & 75.60 \\
\hline & IL32 & G. $\max$ & $\mathrm{IL}$ & - & + & 75.75 \\
\hline & IL33 & G. $\max$ & $\mathrm{IL}$ & - & + & 75.75 \\
\hline & AR3 & G. $\max$ & AR & - & + & 75.70 \\
\hline \multirow[t]{4}{*}{ C. truncatum } & $\mathrm{IL}_{15 \mathrm{~B}^{\mathrm{b}}}$ & G. $\max$ & $\mathrm{IL}$ & - & + & 77.10 \\
\hline & IL16D & G. $\max$ & $\mathrm{IL}$ & - & + & 77.10 \\
\hline & IL28C & G. $\max$ & IL & - & + & 77.15 \\
\hline & AR2 & G. $\max$ & $\mathrm{AR}$ & - & + & 77.10 \\
\hline \multirow[t]{10}{*}{ Glomerella glycines } & IL $18 \mathrm{~A}^{\mathrm{b}}$ & G. $\max$ & IL & + & - & 71.60 \\
\hline & IL19A & G. $\max$ & IL & + & - & 71.65 \\
\hline & IL20A & G. $\max$ & $\mathrm{IL}$ & + & - & 71.60 \\
\hline & IL21A & G. $\max$ & $\mathrm{IL}$ & + & - & 71.60 \\
\hline & IL22A & G. $\max$ & IL & + & - & 71.60 \\
\hline & IL23A & G. $\max$ & IL & + & - & 71.10 \\
\hline & IL24A & G. $\max$ & $\mathrm{IL}$ & + & - & 71.70 \\
\hline & IL25A & G. $\max$ & $\mathrm{IL}$ & + & - & 71.65 \\
\hline & IL26A & G. $\max$ & IL & + & - & 71.65 \\
\hline & IL27B & G. $\max$ & $\mathrm{IL}$ & + & - & 71.60 \\
\hline C. gloeosporioides & ATCC58222 & G. $\max$ & IL & + & - & 71.70 \\
\hline \multirow[t]{2}{*}{ C. coccodes } & ND1 & G. $\max$ & ND & + & + & 72.15 in Set $1 ; 75.75$ in Set 2 \\
\hline & ND3 & G. $\max$ & ND & + & + & 72.10 in Set $1 ; 75.65$ in Set 2 \\
\hline C. acutatum & Cacu 1 & Capsicum & & - & + & 76.60 \\
\hline C. orbiculare & Corb1 & Citrullus & & - & - & N/A \\
\hline \multicolumn{7}{|l|}{ Other fungi } \\
\hline Cercospora kikuchii & AR191 & G. $\max$ & AR & - & - & N/A \\
\hline Fusarium virguliforme & Mont1 & G. $\max$ & & + & + & 71.30 in Set $1 ; 77.85$ in Set 2 \\
\hline Macrophomina phaseolina & Pinetree & G. $\max$ & AR & - & - & N/A \\
\hline Phomopsis longicolla & ATCC60325 & G. $\max$ & $\mathrm{OH}$ & - & + & 79.35 \\
\hline Diaporthe phaseolorum var. caulivora & ATCC28484 & G. $\max$ & $\mathrm{OH}$ & - & + & 79.35 \\
\hline D. phaseolorum var. meridionalis & ATCC200236 & G. $\max$ & GA & - & + & 79.85 \\
\hline D. phaseolorum var. sojae & ATCC28463 & G. $\max$ & $\mathrm{OH}$ & - & + & 78.85 \\
\hline
\end{tabular}

$\mathrm{a}+=$ detectable and $-=$ no amplified product.

b Reference isolates identified with multigene phylogenetic analysis (Yang et al. 2014). 
Phylogenetic analysis. A phylogenetic tree was constructed based on the partial coxl sequences amplified with primers coxul and coxr1 as described above. Cox 1 sequences of 21 isolates, including the four Colletotrichum species studied herein and another four Colletotrichum species (C. acutatum, C. coccodes, C. gloeosporioides, and $C$. orbiculare) selected in Table 2, were aligned using BioEdit v7.1.3 as described above. The alignment was then imported into MEGA 5 software for maximum likelihood phylogenetic analysis (Tamura et al. 2011). The best nucleotide substitution model was tested in MEGA 5, and T92 + G (Tamura 3-parameter + Gamma distribution) was selected because of its lowest Bayesian information criterion score among all models. A phylogenetic tree was constructed using all nucleotide sites with the T92 + G model and nearest-neighbor-interchange as the heuristic approach of maximum likelihood method. The robustness of the tree was estimated with 1,000 bootstrap replications.

\section{Results}

Fungal collection. A total of 240 Colletotrichum isolates were purified and cultured: 13 isolates from Alabama; 3 isolates from Arkansas; 204 isolates from Illinois; 1 isolate from Mississippi; and 19 isolates from North Dakota. Among them, the well-identified isolates (Yang et al. 2014) IL1A, IL6A, IL15B, and IL18A were designated as the reference isolates of $C$. chlorophyti, C. incanum, C. truncatum, and G. glycines, respectively, in this study. Another 31 isolates of the four species and other fungal isolates were selected based on their morphological characteristics and ITS sequences. The origin, host, and real-time PCR results of these isolates were summarized (Table 2).

Real-time PCR. In singleplex real-time PCR (Fig. 2), the dissociation curve analyses showed that each primer pair (Table 1) amplified a single product for its target species and no product for the other three species, indicating the specificity of the primer pairs to detect their corresponding Colletotrichum species. The individual peaks in dissociation curves of the amplicons from the four singleplex real-time PCR reactions showed unique $\mathrm{T}_{\mathrm{m}}$ values $\left(71.6^{\circ} \mathrm{C}\right.$ for G. glycines isolate IL18A, $75.75^{\circ} \mathrm{C}$ for C. chlorophyti isolate IL1A, $76.15^{\circ} \mathrm{C}$ for $C$. incanum isolate IL6A, and $78.0^{\circ} \mathrm{C}$ for $C$. truncatum isolate IL15B) adequate for differentiation and identification.

When the four primer pairs were mixed together for quadruplex real-time PCR, the dissociation curve of $G$. glycines exhibited multiple peaks whereas the other three primer sets produced single peaks (Fig. 3) similar to those found in singleplex assays. In addition, the $\mathrm{T}_{\mathrm{m}}$ values of $C$. chlorophyti $\left(75.25^{\circ} \mathrm{C}\right)$ and $C$. incanum $\left(75.65^{\circ} \mathrm{C}\right)$ in the quadruplex assay were close to each other even though they had distinct peaks.

To reduce the multiple peaks produced by $G$. glycines and to resolve the adjacent peaks of $C$. chlorophyti and $C$. incanum, the quadruplex was divided into two sets of duplex real-time PCR. Set 1 detected C. chlorophyti and G. glycines, and Set 2 detected C. incanum and C. truncatum. Reference isolates IL1A, IL6A, IL15B, and IL18A tested in the two duplex assays showed single peaks and specificity to their expected species (Fig. 4). The differentiation was achieved with specific $T_{m}$ values for each species. The $T_{m}$ values were: $75.36 \pm 0.25^{\circ} \mathrm{C}$ for $C$. chlorophyti and $71.63 \pm 0.22^{\circ} \mathrm{C}$ for G. glycines in Set $1 ; 75.79 \pm 0.23^{\circ} \mathrm{C}$ for $C$. incanum and $77.39 \pm$ $0.34^{\circ} \mathrm{C}$ for $C$. truncatum in Set 2 (Table 1).

Sensitivity and specificity of the duplex real-time PCR assays. Detection sensitivity of the two duplex real-time PCR assays (Table 3) showed that in the Set 1 assay, C. chlorophyti and G. glycines both were detectable when the amount of DNA in the reaction was at least $1 \mathrm{pg}$. In the Set 2 assay, $C$. incanum was detectable when the amount of DNA added to the reaction was at least $1 \mathrm{pg}$; detection of $C$. truncatum was somewhat more sensitive, as weak amplification was observed for 0.1-pg late cycles of PCR (threshold cycle, $\mathrm{Ct}=$ 29.92; Table 3). All standard curves of the four Colletotrichum species exhibited efficiencies of greater than $90 \%$.

The specificity of the duplex assays was validated with sequences that identified Colletotrichum isolates and other fungal species (Table 2). All of the isolates in the collection that belonged to C. chlorophyti, C. incanum, C. truncatum, or G. glycines were identified correctly by the two duplex assays. However, one ATCC strain of $C$. gloeosporioides $\left(\mathrm{T}_{\mathrm{m}}=71.70^{\circ} \mathrm{C}\right)$ was also detected in Set 1 with the same $\mathrm{T}_{\mathrm{m}}$ as $G$. glycines $\left(\mathrm{T}_{\mathrm{m}}=71.63 \pm 0.22^{\circ} \mathrm{C}\right)$. For other Colletotrichum species, $C$. coccodes was detectable in both duplex assays but could be distinguished from the four reference Colletotrichum species because of its $\mathrm{T}_{\mathrm{m}}$ value (average $72.13^{\circ} \mathrm{C}$ in Set 1 and $75.70^{\circ} \mathrm{C}$ in Set 2); C. acutatum was weakly detected in Set 2 , but only after 29 cycles, and it had a unique $\mathrm{T}_{\mathrm{m}}$ value $\left(76.60^{\circ} \mathrm{C}\right)$ that was different from $C$. incanum and C. truncatum; C. orbiculare was not detected in either Set 1 or Set 2 assays. Other fungal isolates tested in this study had no amplified products or had peaks with very different $\mathrm{T}_{\mathrm{m}}$ values in dissociation

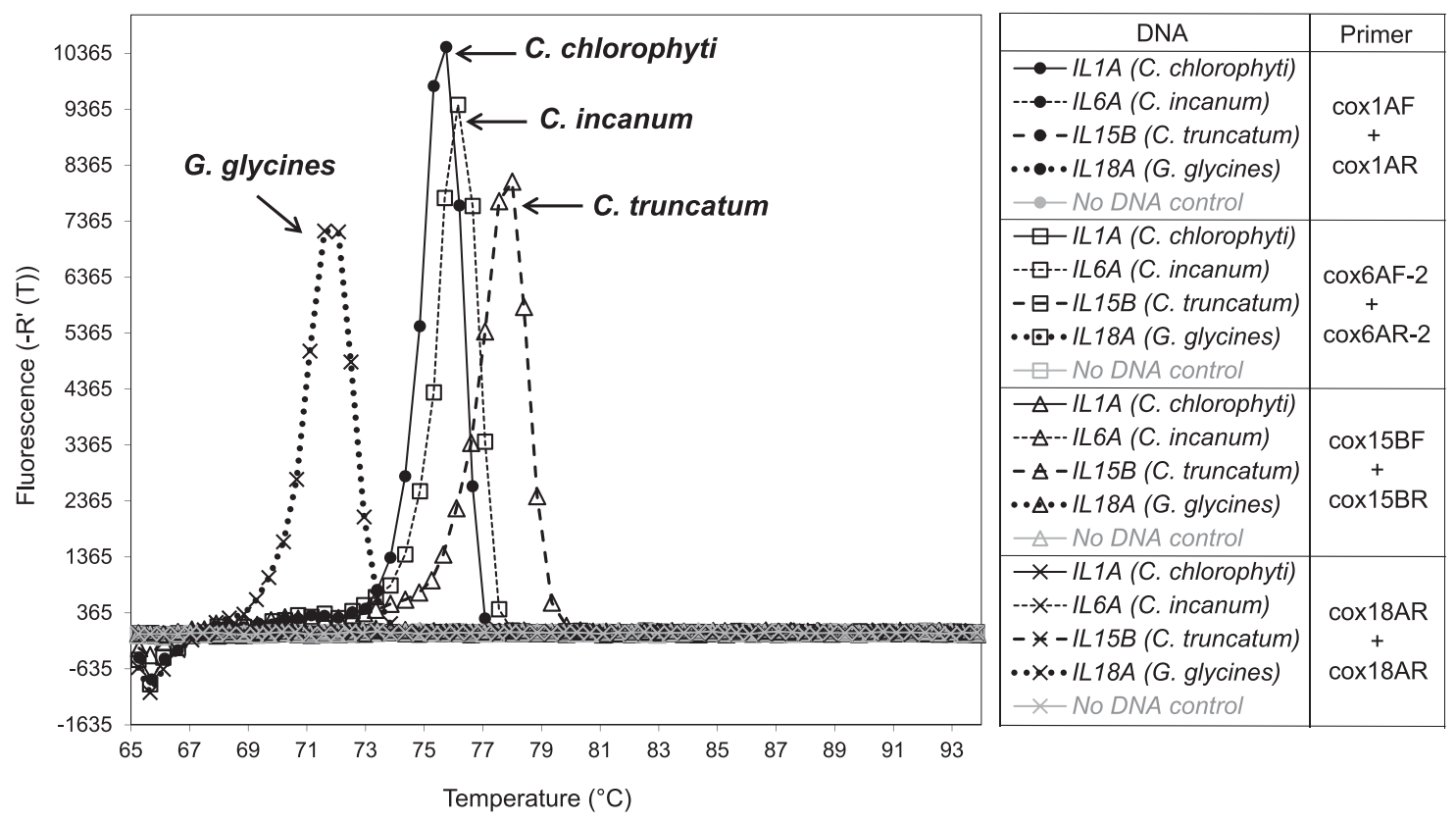

Fig. 2. Dissociation curves of four Colletotrichum species (C. chlorophyti, C. incanum, C. truncatum, and Glomerella glycines) from singleplex real-time PCR using one primer pair in one reaction. The designed primer pairs are shown to specifically detect their corresponding Colletotrichum species, and the amplicons show distinct peaks with melting point temperatures that can be distinguished from one another. All the other reactions have no products amplified. 
curves that could be separated from the four Colletotrichum species studied herein (Table 2).

Identification of isolates in the Colletotrichum collection using real-time PCR. In addition to the Colletotrichum isolates listed in Table 2, 205 purified isolates in our collection initially classified as Colletotrichum species by visual observation (formation of acervuli and/or perithecia and the cultural characteristics) were successfully identified at the species level using two duplex real-time PCR assays. In summary, of 240 isolates, 107 (44.6\%) were identified as G. glycines or $C$. gloeosporioides (for the two species had the same pattern in the dissociation curve analysis), 83 as C. incanum (34.6\%), 24 as C. truncatum (10\%), 23 as C. chlorophyti $(9.6 \%)$, and 3 as C. coccodes $(1.3 \%)$ (Table 4$)$. Among the 204 isolates collected in Illinois, nearly $50 \%$ were $G$. glycines or C. gloeosporioides, $30 \%$ were C. incanum, $8 \%$ were C. chlorophyti, and $7 \%$ were $C$. truncatum. All three $C$. coccodes isolates were from North Dakota.

Phylogenetic analysis. The phylogenetic tree based on coxl sequences from 21 Colletotrichum isolates (eight species) delimited a cladistic boundary (Fig. 5). Colletotrichum coccodes and $C$. incanum were grouped with a bootstrap value of 88 and then grouped with $C$. acutatum to form a larger clade with a bootstrap value of 98 , indicating that the three species were more closely related than the other species tested. Both $C$. chlorophyti and $C$. truncatum formed individual clades with bootstrap values of 99 and 97, respectively. Isolates of $G$. glycines grouped together with a bootstrap value of 100, and the ATCC strain of C. gloeosporioides further formed a clade with $G$. glycines with a bootstrap value of 97 . The high similarity of the coxl regions of $G$. glycines and $C$. gloeosporioides made them indistinguishable in the real-time PCR assay (the duplex Set 1). The cox 1 sequence of $C$. orbiculare was different from all the others and thus it was considered as an outgroup.

\section{Discussion}

Four Colletotrichum species associated with plants were identified by morphological characteristics and sequence analyses. Real-time multiplex PCR assays using part of the coxl gene discerned these four Colletotrichum species. Two sets of duplex real-time PCR assays based upon amplicon melting-point temperatures differentiated C. chlorophyti and G. glycines (not distinguished from C. gloeosporioides), and differentiated $C$. incanum and $C$. truncatum. The two real-time duplex PCR assays were used to detect more than 200 isolates in the Colletotrichum species collection showing that it was a rapid and effective method to identify Colletotrichum species infecting soybean.

Although the two duplex assays were focused and utilized for screening our collection in this study, an alternative triplex realtime PCR combining primers targeting $C$. chlorophyti, $C$. incanum, and $C$. truncatum can be used, as correct detection was not impacted with this primer combination, as shown in quadruplex real-time PCR (Fig. 3). Glomerella glycine could be assayed separately in that it has straight conidia and forms perithecia that are different from the other three species (Manandhar et al. 1986). The application of the triplex real-time PCR for identification and differentiation of C. chlorophyti, C. incanum, and C. truncatum is useful because these three species all have curved conidia and similar morphological characteristics that are not easily distinguished by visual examination (Yang et al. 2012; 2014). Colletotrichum truncatum has been most commonly attributed as the soybean anthracnose pathogen (Manandhar and Hartman 1999). However, the present study showed that $C$. incanum accounted for one-third of the Illinois isolates, with fewer isolates of $C$. truncatum and C. chlorophyti. To further elucidate their association with soybean anthracnose and appraise the economic impact, the triplex real-time PCR assay could be a useful augmentation to visual examination for distinguishing these three species bearing similar morphological features.

Most of the tested fungi were differentiated from the four Colletotrichum species in the two duplex assays, showing no or weak amplification ( $\mathrm{Ct}>29$ cycles) and/or different numbers or $\mathrm{T}_{\mathrm{m}}$ values of their dissociation peaks. The exception was $C$. gloeosporioides, which was not discriminated from G. glycines. Both species were reported to infect soybean (Manandhar and Hartman 1999). Glomerella glycines has aparaphysate perithecia and long allantoid ascospores, while $C$. gloeosporioides has paraphysate perithecia and short cylindrical ascospores (Tiffany and Gilman 1954; Manandhar et al. 1986). In addition to morphological differences, they can be discriminated by sequence analysis. Thus, these two species are readily differentiated, though not by our multiplex assays.

Experiments testing the performance of the two duplex assays on samples with different combinations of DNAs of the four Colletotrichum species were also conducted (data not shown). The results showed that the assays could not distinguish Colletotrichum samples when a reaction contained mixed DNAs of C. chlorophyti and G. glycines, which resulted in only the one major peak of $C$. chlorophyti in the Set 1 assay, or mixed DNAs of $C$. incanum and $C$. truncatum,

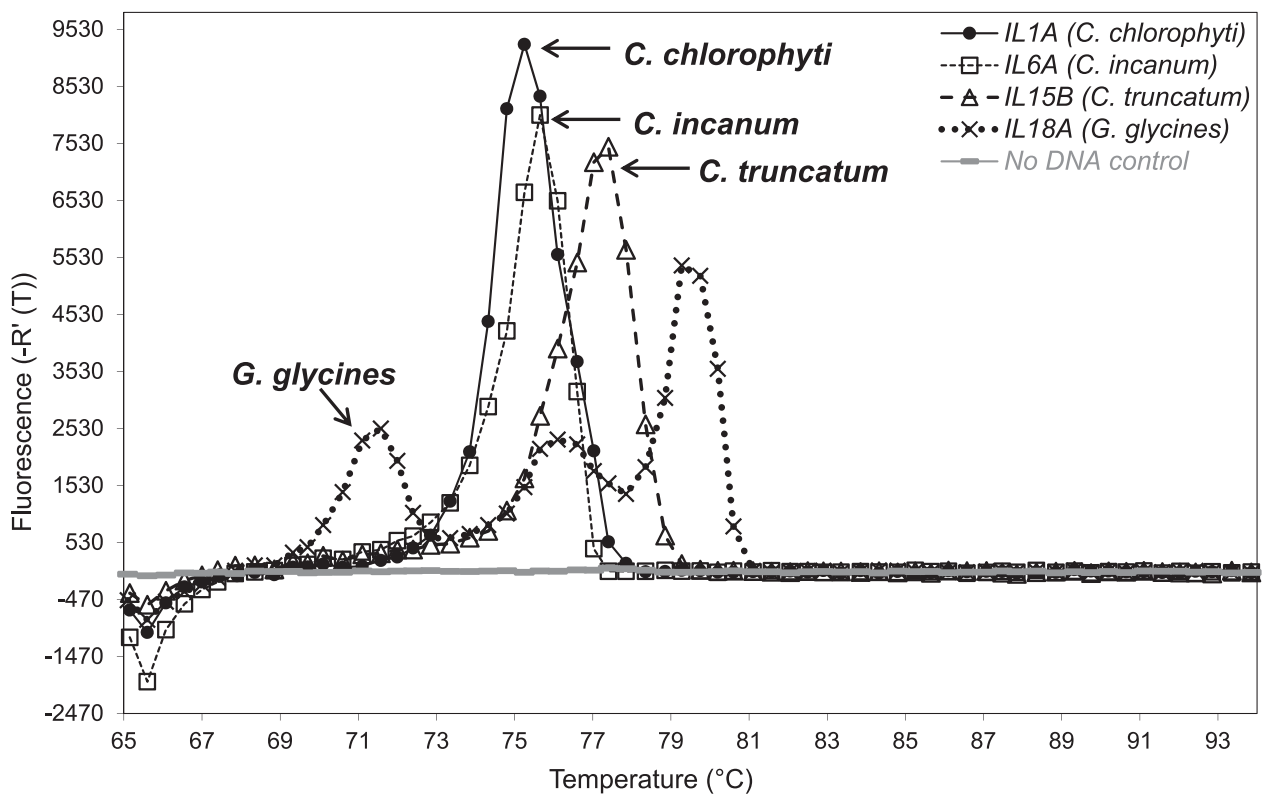

Fig. 3. Dissociation curves of four Colletotrichum species from quadruplex real-time PCR using four primer pairs in one reaction. Glomerella glycines shows multiple peaks, while the other three species show only single peaks. 
which resulted in mixed peaks in the Set 2 assay. One possible explanation is the interactions of the mixed genomic DNA combinations that affected primer annealing or reaction efficiency. A study using dissociation curve analysis to detect three sugarcane root-knot nematodes also found the competition effect between mixed species in multiplex real-time PCR (Berry et al. 2008). Because field samples can have more than one Colletotrichum species present, the current real-time PCR assays may not be suitable for field diagnostics. In spite of that limitation, the real-time PCR assays detected and distinguished individually purified Colletotrichum isolates. They can therefore serve as useful tools when a purified Colletotrichum species isolated from soybean requires identification.

A probe-based quantitative PCR assay using ITS region sequences has been previously developed to detect and quantify members of the Colletotrichum genus (J. S. Haudenshield, unpublished data); however, the present study focused on differentiating among Colletotrichum species infecting soybean. The differences in ITS sequences among four Colletotrichum species (C. chlorophyti, C. incanum, $C$. truncatum, and G. glycines) were examined first but did not produce suitable real-time PCR primers for all of them. Divergent sequences were not found among the coxl gene for the four Colletotrichum species to permit the design of a probe-based assay such as Taqman; however, an intercalating dsDNA dye-binding assay differentiated the species by comparing $\mathrm{T}_{\mathrm{m}}$ estimations in dissociation curve analyses. In a preliminary test of comparing the performance of two fluorescent dyes EvaGreen and SYBR Green (Life Technologies, Grand Island, NY), results showed that the amplification signals and dissociation peaks detected in SYBR Green assays were not as strong and sharp as those in EvaGreen assays (data not shown), indicating the greater detection sensitivity of EvaGreen dye. This
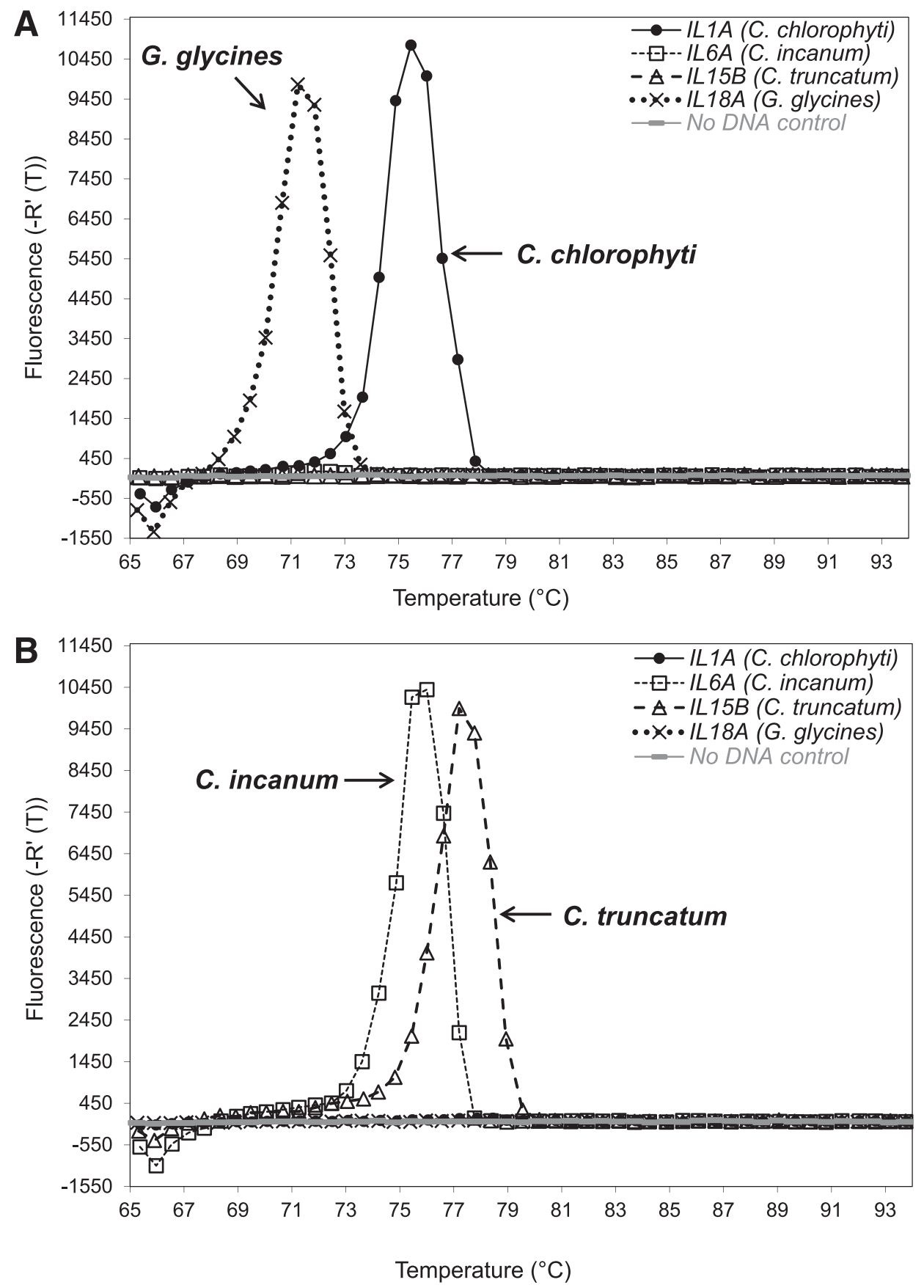

Fig. 4. Dissociation curves of two duplex real-time PCR assays, each detecting and differentiating two Colletotrichum species. A, Set 1 detects $\mathrm{C}$. chlorophyti and Glomerella glycines. B, Set 2 detects $C$. incanum and $C$. truncatum. 
was also found previously when EvaGreen- and SYBR Green I-based real-time PCR assays were compared, and the former showed better reproducibility, peak resolution, and higher tolerance of dye concentration than the latter (Mao et al. 2007; Khan et al. 2011). The present real-time PCR assays yielded qualitative results but also allowed for quantitative analysis simultaneously as long as a single isolate was used.

In recent years, high resolution melting (HRM) analysis was developed (Wittwer et al. 2003) and has been used for DNA genotyping and molecular diagnostics (Montgomery et al. 2007). This automated technique was also based on real-time PCR using intercalating dsDNA-binding dye but with increased resolution in melting curve analysis. Ganopoulos et al. (2012) used the HRM method to successfully discriminate the plant pathogen Fusarium oxyporum complex with the ITS region. Seven $F$. oxysporum formae speciales with very similar ITS sequences could be distinguished by generating seven individual HRM curves with different peak numbers, shapes, and $\mathrm{T}_{\mathrm{m}}$ values. The results revealed the potential of real-time PCR coupled with dissociation curve analysis to serve as a powerful tool to identify and differentiate plant fungal pathogens within the same genus that

Table 3. Detection sensitivity of the four Colletotrichum species in the two duplex real-time PCR assays. Successful detection was achieved when the DNA amount was $\geq 1 \mathrm{pg}$ for all species

\begin{tabular}{|c|c|c|c|c|}
\hline $\begin{array}{l}\text { PCR } \\
\text { duplex }\end{array}$ & Species (isolate) & $\begin{array}{c}\text { DNA }^{\mathbf{a}} \\
(\mathbf{p g})\end{array}$ & $\begin{array}{c}\mathbf{C t}^{\mathbf{a}} \\
(\mathbf{d R n})\end{array}$ & $\begin{array}{l}\text { Product } \\
T_{m}\left({ }^{\circ} \mathrm{C}\right) \\
\end{array}$ \\
\hline \multirow[t]{12}{*}{$\overline{\text { Set } 1}$} & \multirow[t]{6}{*}{ C. chlorophyti (IL1A) } & 100 & 20.37 & 75.85 \\
\hline & & 10 & 23.97 & 75.35 \\
\hline & & 1 & 27.43 & 75.33 \\
\hline & & 0.1 & $\mathrm{No} C t$ & - \\
\hline & & 0.01 & $\mathrm{No} C t$ & - \\
\hline & & $\mathrm{H}_{2} \mathrm{O}$ & $\mathrm{No} C t$ & - \\
\hline & \multirow{6}{*}{$\begin{array}{l}\text { Glomerealla glycines } \\
\text { (IL18A) }\end{array}$} & 100 & 21.7 & 71.85 \\
\hline & & 10 & 25.23 & 71.85 \\
\hline & & 1 & 28.38 & 71.80 \\
\hline & & 0.1 & $\mathrm{No} C t$ & - \\
\hline & & 0.01 & $\mathrm{No} C t$ & - \\
\hline & & $\mathrm{H}_{2} \mathrm{O}$ & $\mathrm{No} C t$ & - \\
\hline \multirow[t]{12}{*}{ Set 2} & \multirow[t]{6}{*}{ C. incanum (IL6A) } & 100 & 21.07 & 75.85 \\
\hline & & 10 & 24.66 & 75.85 \\
\hline & & 1 & 27.89 & 75.83 \\
\hline & & 0.1 & No Ct & - \\
\hline & & 0.01 & $\mathrm{No} C t$ & - \\
\hline & & $\mathrm{H}_{2} \mathrm{O}$ & $\mathrm{No} C t$ & - \\
\hline & \multirow[t]{6}{*}{ C. truncatum (IL15B) } & 100 & 19.85 & 77.85 \\
\hline & & 10 & 23.1 & 77.35 \\
\hline & & 1 & 26.76 & 77.85 \\
\hline & & 0.1 & 29.92 & 77.85 \\
\hline & & 0.01 & $\mathrm{No} C t$ & - \\
\hline & & $\mathrm{H}_{2} \mathrm{O}$ & $\mathrm{No} C t$ & - \\
\hline
\end{tabular}

a Standard curves (DNA quantity versus Ct): IL1A: $\mathrm{Y}=-3.534 \log (\mathrm{X})+$ $27.46\left(\mathrm{R}^{2}=1.000\right.$, efficiency $\left.=91.9 \%\right)$; IL18A: $\mathrm{Y}=-3.340 \log (\mathrm{X})+$ $28.44\left(R^{2}=0.999\right.$, efficiency $\left.=99.3 \%\right)$; IL6A: $\mathrm{Y}=-3.412 \log (\mathrm{X})+27.95$ $\left(\mathrm{R}^{2}=0.999\right.$, efficiency $\left.=96.4 \%\right) ; \mathrm{IL} 15 \mathrm{~B}: \mathrm{Y}=-3.388 \log (\mathrm{X})+26.60$ $\left(R^{2}=0.999\right.$, efficiency $\left.=97.3 \%\right)$.

Table 4. Number of Colletotrichum isolates collected from five states and identified using two duplex real-time PCR assays

\begin{tabular}{|c|c|c|c|c|c|c|c|}
\hline \multirow[b]{2}{*}{ Colletotrichum sp. } & \multicolumn{5}{|c|}{ State } & \multirow[b]{2}{*}{ Total } & \multirow[b]{2}{*}{$\%$} \\
\hline & $\mathbf{A L}$ & $\mathbf{A R}$ & IL & MS & ND & & \\
\hline $\begin{array}{l}\text { Glomerella glycines } \\
\text { or C. gloeosporioides }\end{array}$ & 2 & 0 & 104 & 0 & 1 & 107 & 44.6 \\
\hline C. incanum & 0 & 1 & 67 & 0 & 15 & 83 & 34.6 \\
\hline C. truncatum & 8 & 1 & 15 & 0 & 0 & 24 & 10.0 \\
\hline C. chlorophyti & 3 & 1 & 18 & 1 & 0 & 23 & 9.6 \\
\hline C. coccodes & 0 & 0 & 0 & 0 & 3 & 3 & 1.3 \\
\hline Total & 13 & 3 & 204 & 1 & 19 & 240 & 100 \\
\hline
\end{tabular}

are morphologically similar and which otherwise require laborious effort for accurate identification. Our study using conventional dissociation analysis could be extended and applied to the more sensitive HRM analysis in the future.

The coxl gene has been widely used for animal DNA barcoding owing to its good taxonomic resolution (Hebert et al. 2003). Although coxl was also reported to be good at resolving the phylogeny of Ascomycota and Zygomycota (Molitor et al. 2010), it was not suitable for Basidiomycota phylogenetic analysis (Vialle et al. 2009; Dentinger et al. 2011) and has been excluded as a universal barcoding marker for fungi because of its difficulty in amplifying DNA from some species, lower divergence, and the existence of large introns (Begerow et al. 2010; Schoch et al. 2012). The present study showed that the coxl gene successfully grouped Colletotrichum spp. at the species level in the phylogenetic tree, and the EvaGreen-based real-time PCR assays were successfully established according to the differences among the sequences. Since the assays were designed on a translated gene, the mitochondrial $\operatorname{cox} 1$, they could be adapted and used to determine the metabolic activity of the live fungus as well as to monitor the infection progress of the target species using reverse transcription real-time PCR. Our results suggest that coxl remains a useful candidate target for detecting fungi in PCR assays as long as appropriate primers can be designed.

With the two duplex real-time PCR assays, more than 200 Colletotrichum isolates collected from soybean in several U.S. states were identified to species. It was interesting to note that $C$. coccodes was only found in North Dakota and not in other states. Colletotrichum coccodes is known to be a common pathogen of potato, causing potato black dot (Tsror (Lahkim) and Johnson 2000). North Dakota produces about $5 \%$ of the total annual U.S. potato crop (Agriculture 2000), and it is possible that the fields where $C$. coccodes was recovered from soybean had potato growing in the past. Further research is needed to determine if $C$. coccodes would be



Fig. 5. Maximum likelihood phylogenetic tree of the partial cox1 gene from 21 isolates consisting of eight Colletotrichum species. The GenBank accession numbers are given in parentheses. The numbers at nodes indicate bootstrap support values with 1,000 replications. Only bootstrap values above $70 \%$ are shown. 
a greater problem in cropping systems rotated with potato and soybean.

Based on the screening results of the real-time PCR assays developed in our study, G. glycine and/or C. gloeosporioides accounted for nearly $51 \%$ (104 of 204 isolates) of the Colletotrichum isolates collected in Illinois. In addition, the recently identified and newly named $C$. incanum (Yang et al. 2014) was also commonly recovered and accounted for 35\% (83 of 240 isolates) and 33\% (67 of 204 isolates) of the collection in total and in Illinois, respectively. Since the morphology of $C$. chlorophyti, C. incanum, and $C$. truncatum are similar, previous literature citations about $C$. truncatum may include the other two species. As the current results were based on limited collections and data, a thorough survey is needed to clarify the distribution and impact of these Colletotrichum species. The real-time PCR methods established in this study can serve as a tool for this purpose.

In conclusion, this study developed dsDNA-binding dye based real-time PCR assays to efficiently detect and differentiate pure isolates of Colletotrichum species infecting soybean. To our knowledge, this is the first report to utilize multiplex real-time PCR with dissociation curve analysis for identification and differentiation of Colletotrichum species associated with soybean at the species level. The method used in our study allows for more multiplex detection and is more cost effective compared with most prevalent probe-based real-time PCR assays. The method can serve as a useful tool for disease diagnosis and investigation of soybean anthracnose and potentially other pathogens.

\section{Acknowledgments}

We thank Drs. C. R. Bowen and S. C. Chawla (Illinois), E. Sikora (Alabama), J. Rupe (Arkansas), M. Wunsch (North Dakota), and T. Allen (Mississippi) for providing soybean samples from the fields. This research was funded in part by the United States Department of Agriculture-Agricultural Research Service.

\section{Literature Cited}

Agriculture 2000. Crop profile for potatoes in North Dakota. Office of Pest Manage. Policy and Nat. Agric. Pesticide Impact Assessment Prog. (NAPIAP), Fargo, ND. http://www.ag.ndsu.nodak.edu/aginfo/entomology/ndpiap/ND_Crop_Profiles/Potato/ crop_profile_for_potatoes_in_ND.htm, April 2015.

Arx, J. A. V. 1957. The species of the genus Colletotrichum Cda. Phytopathol. Z. 29:413-468.

Backman, P. A., Williams, J. C., and Crawford, M. A. 1982. Yield losses in soybeans from anthracnose caused by Colletotrichum truncatum. Plant Dis. 66:1032-1034

Barletta, F., Ochoa, T. J., and Cleary, T. G. 2013. Multiplex real-time PCR (MRTPCR) for diarrheagenic. Methods Mol. Biol. 943:307-314.

Bates, J. A., Taylor, E. J. A., Gans, P. T., and Thomas, J. E. 2002. Determination of relative proportions of Globodera species in mixed populations of potato cyst nematodes using PCR product melting peak analysis. Mol. Plant Pathol. 3:153-161.

Begerow, D., Nilsson, H., Unterseher, M., and Maier, W. 2010. Current state and perspectives of fungal DNA barcoding and rapid identification procedures. Appl. Microbiol. Biotechnol. 87:99-108.

Berry, S. D., Fargette, M., Spaull, V. W., Morand, S., and Cadet, P. 2008. Detection and quantification of root-knot nematode (Meloidogyne javanica), lesion nematode (Pratylenchus zeae) and dagger nematode (Xiphinema elongatum) parasites of sugarcane using real-time PCR. Mol. Cell. Probes 22:168-176.

Chai, Z., Ma, W., Fu, F., Lang, Y., Wang, W., Tong, G., Liu, Q., Cai, X., and Li, X. 2013. A SYBR Green-based real-time RT-PCR assay for simple and rapid detection and differentiation of highly pathogenic and classical type 2 porcine reproductive and respiratory syndrome virus circulating in China. Arch. Virol. 158:407-415.

Chen, L. S., Chu, C., Liu, C. D., Chen, R. S., and Tsay, J. G. 2006. PCR-based detection and differentiation of anthracnose pathogens, Colletotrichum gloeosporioides and C. truncatum, from vegetable soybean in Taiwan. J. Phytopathol. 154:654-662.

Cheng, J., Jiang, Y., Rao, P., Wu, H., Dong, Q., Wu, Z., Ding, X., and Guo, J. 2013. Development of a single-tube multiplex real-time PCR for detection and identification of five pathogenic targets by using melting-curve analysis with EvaGreen. Arch. Virol. 158:379-386.

Cullen, D. W., Lees, A. K., Toth, I. K., and Duncan, J. M. 2002. Detection of Colletotrichum coccodes from soil and potato tubers by conventional and quantitative real-time PCR. Plant Pathol. 51:281-292.

Damm, U., Liu, F., Cannon, P.F., and Crous, P.W. 2013. Unraveling legume anthracnose pathogens. Phytopathology 103(Suppl. 2):S2.33.

Damon, C., Barroso, G., Ferandon, C., Ranger, J., Fraissinet-Tachet, L., and Marmeisse, R. 2010. Performance of the COX1 gene as a marker for the study of metabolically active Pezizomycotina and Agaricomycetes fungal communities from the analysis of soil RNA. FEMS Microbiol. Ecol. 74 693-705.

Debode, J., Van Hemelrijck, W., Baeyen, S., Creemers, P., Heungens, K., and Maes, M. 2009. Quantitative detection and monitoring of Colletotrichum acutatum in strawberry leaves using real-time PCR. Plant Pathol. 58:504-514.

Deepak, S. A., Kottapalli, K. R., Rakwal, R., Oros, G., Rangappa, K. S., Iwahashi, H., Masuo, Y., and Agrawal, G. K. 2007. Real-time PCR: Revolutionizing detection and expression analysis of genes. Curr. Genomics 8:234-251.

Dentinger, B. T. M., Didukh, M. Y., and Moncalvo, J.-M. 2011. Comparing COI and ITS as DNA barcode markers for mushrooms and allies (Agaricomycotina) PLoS One 6:e25081.

Fricke, S., Fricke, C., Oelkrug, C., Blatz, R., Schoenfelder, U., Niederwieser, D., Hilger, N., Ruhnke, M., and Rodloff, A. C. 2012. A real-time PCR for the detection and characterisation of Aspergillus species. Mycoses 55:416-425.

Ganopoulos, I., Madesis, P., Zambounis, A., and Tsaftaris, A. 2012. Highresolution melting analysis allowed fast and accurate closed-tube genotyping of Fusarium oxysporum formae speciales complex. FEMS Microbiol. Lett. 334:16-21.

Garrido, C., Carbu, M., Fernandez-Acero, F. J., Boonham, N., Colyer, A., Cantoral, J. M., and Budge, G. 2009. Development of protocols for detection of Colletotrichum acutatum and monitoring of strawberry anthracnose using real-time PCR. Plant Pathol. 58:43-51.

Hall, T. A. 1999. BioEdit: a user-friendly biological sequence alignment editor and analysis program for Windows 95/98/NT. Nucleic Acids Symp. Ser. 41:95-98.

Hays, C., Duhamel, C., Cattoir, V., and Bonhomme, J. 2011. Rapid and accurate identification of species belonging to the Candida parapsilosis complex by real-time PCR and melting curve analysis. J. Med. Microbiol. 60:477-480.

Hebert, P. D. N., Cywinska, A., Ball, S. L., and DeWaard, J. R. 2003. Biological identifications through DNA barcodes. Proc. R. Soc. Lond. B Biol. Sci. 270: 313-321.

Hillis, D. M., and Dixon, M. T. 1991. Ribosomal DNA - molecular evolution and phylogenetic inference. Q. Rev. Biol. 66:411-453.

Horisawa, S., Sakuma, Y., and Doi, S. 2013. Identification and species-typing of wood rotting fungi using melting curve analysis. J. Wood Sci. 59:432-441.

Khan, S. A., Sung, K., and Nawaz, M. S. 2011. Detection of aacA-aphD, qacE delta 1, marA, floR, and tetA genes from multidrug-resistant bacteria: Comparative analysis of real-time multiplex PCR assays using EvaGreen and SYBR Green I dyes. Mol. Cell. Probes 25:78-86.

Kuan, C.-P., Wu, M.-T., Huang, H. C., and Chang, H. 2011. Rapid detection of Colletotrichum lagenarium, causal agent of anthracnose of Cucurbitaceous crops, by PCR and real-time PCR. J. Phytopathol. 159:276-282.

Manandhar, J. B., and Hartman, G. L. 1999. Anthracnose. Pages 13-14. in: Compendium of Soybean Diseases. G. L. Hartman, J. B. Sinclair, and J. C. Rupe, eds. APS Press, St. Paul, MN.

Manandhar, J. B., Hartman, G. L., and Sinclair, B. 1986. Colletotrichum destructivum, the anamorph of Glomerella glycines. Phytopathology 76:282-285.

Mangold, K. A., Manson, R. U., Koay, E. S. C., Stephens, L., Regner, M., Thomson, R. B., Peterson, L., and Kaul, K. L. 2005. Real-time PCR for detection and identification of Plasmodium spp. J. Clin. Microbiol. 43:2435-2440.

Mao, F., Leung, W.-Y., and Xin, X. 2007. Characterization of EvaGreen and the implication of its physicochemical properties for qPCR applications. BMC Biotechnol. 7:76.

Molitor, C., Inthavong, B., Sage, L., Geremia, R. A., and Mouhamadou, B. 2010. Potentiality of the coxl gene in the taxonomic resolution of soil fungi. FEMS Microbiol. Lett. 302:76-84

Montgomery, J., Wittwer, C. T., Palais, R., and Zhou, L. 2007. Simultaneous mutation scanning and genotyping by high-resolution DNA melting analysis. Nat. Protoc. 2:59-66

Nicholson, R. L. 1992. Colletotrichum graminicola and the anthracnose disease of maize and sorghum. Pages 186-202. in: Colletotrichum: Biology, Pathogenicity and Control. J. A. Bailey, and M. J. Jeger, eds. CAB International, Wallingford, UK.

Polley, S. D., Boadi, S., Watson, J., Curry, A., and Chiodini, P. L. 2011. Detection and species identification of microsporidial infections using SYBR Green realtime PCR. J. Med. Microbiol. 60:459-466.

Riccioni, L., Conca, G., and Hartman, G. L. 1998. First report of Colletotrichum coccodes on soybean in the United States. Plant Dis. 82:959.

Roy, K. W. 1982. Seedling diseases caused in soybean by species of Colletotrichum and Glomerella. Phytopathology 72:1093-1096.

Schena, L., Nigro, F., Ippolito, A., and Gallitelli, D. 2004. Real-time quantitative PCR: a new technology to detect and study phytopathogenic and antagonistic fungi. Eur. J. Plant Pathol. 110:893-908.

Schoch, C. L., Seifert, K. A., Huhndorf, S., Robert, V., Spouge, J. L., Levesque, C. A., and Chen, W., and Fungal Barcoding Association. 2012. Nuclear ribosomal internal transcribed spacer (ITS) region as a universal DNA barcode marker for Fungi. Proc. Natl. Acad. Sci. USA 109:6241-6246.

Sherriff, C., Whelan, M. J., Arnold, G. M., Lafay, J. F., Brygoo, Y., and Bailey, J. A. 1994. Ribosomal DNA sequence analysis reveals new species groupings in the genus Colletotrichum. Exp. Mycol. 18:121-138.

Steer, P. A., Kirkpatrick, N. C., O'Rourke, D., and Noormohammadi, A. H. 2009 Classification of fowl adenovirus serotypes by use of high-resolution meltingcurve analysis of the hexon gene region. J. Clin. Microbiol. 47:311-321. 
Sutton, B. C. 1980. The Coelomycetes. Fungi imperfecti with pycnidia, acervuli and stromata. Commonwealth Mycological Institute, Kew, UK.

Sutton, B. C. 1992. The genus Glomerella and its anamorph Colletotrichum. Pages 1-26. in: Colletotrichum: Biology, Pathogenicity and Control. J. A. Bailey, and M. J. Jeger, eds. CAB International, Wallingford, UK.

Tamura, K., Peterson, D., Peterson, N., Stecher, G., Nei, M., and Kumar, S. 2011. MEGA5: Molecular evolutionary genetics analysis using maximum likelihood, evolutionary distance, and maximum parsimony methods. Mol. Biol. Evol. 28: 2731-2739.

Tao, G., Hyde, K. D., and Cai, L. 2013. Species-specific real-time PCR detection of Colletotrichum kahawae. J. Appl. Microbiol. 114:828-835.

Thaung, M. 2008. Coelomycete systematics with special reference to Colletotrichum. Mycoscience 49:345-350.

Thompson, J. D., Higgins, D. G., and Gibson, T. J. 1994. CLUSTAL W: Improving the sensitivity of progressive multiple sequence alignment through sequence weighting, position-specific gap penalties and weight matrix choice. Nucleic Acids Res. 22:4673-4680.

Tiffany, L. H., and Gilman, J. C. 1954. Species of Colletotrichum from legumes. Mycologia 46:52-75

Tsror (Lahkim). L., and Johnson, D.A. 2000. Colletotrichum coccodes on potato. Pages 362-373 in: Colletotrichum: Host specificity, pathology and hostpathogen interaction. D. Prusky, S. Freeman, and M.B. Dickman, eds. APS Press, St. Paul, MN.
Vialle, A., Feau, N., Allaire, M., Didukh, M., Martin, F., Moncalvo, J. M., and Hamelin, R. C. 2009. Evaluation of mitochondrial genes as DNA barcode for Basidiomycota. Mol. Ecol. Resour. 9:99-113.

White, T. J., Bruns, T., Lee, S., and Taylor, J. 1990. Amplification and direct sequencing of fungal ribosomal RNA genes for phylogenetics. Pages 315-322. in: PCR Protocols: A Guide to Methods and Applications. M. A. Innis, D. H. Gelfand, J. J. Sninsky, and T. J. White, eds. Academic Press, San Diego, CA.

Wieczorek, P., and Obrepalska-Steplowska, A. 2013. Multiplex RT-PCR reaction for simultaneous detection of Tomato torrado virus and Pepino mosaic virus coinfecting Solanum lycopersicum. J. Plant Prot. Res. 53:289-294.

Wittwer, C. T., Reed, G. H., Gundry, C. N., Vandersteen, J. G., and Pryor, R. J. 2003. High-resolution genotyping by amplicon melting analysis using LCGreen. Clin. Chem. 49:853-860.

Wrather, J. A., and Koenning, S. R. 2006. Estimates of disease effects on soybean yields in the United States 2003 to 2005. J. Nematol. 38:173-180.

Yang, H.-C., Haudenshield, J. S., and Hartman, G. L. 2012. First report of Colletotrichum chlorophyti causing soybean anthracnose. Plant Dis. 96:1699.

Yang, H.-C., Haudenshield, J. S., and Hartman, G. L. 2014. Colletotrichum incanum sp. nov., a curved-conidial species causing soybean anthracnose in the USA. Mycologia 106:32-42.

Yang, H.-C., Stewart, J. M., and Hartman, G. L. 2013. First report of Colletotrichum chlorophyti infecting soybean seed in Arkansas, United States. Plant Dis. 97:1510. 